\title{
БІОЕЛЕКТРИЧНІ ПОТЕНЦІАЛИ ДУБА І ЛИПИ В ДЕРЕВОСТАНАХ СВІЖОЇ ГРАБОВОЇ ДІБРОВИ ЗАХІДНОГО ПОДІЛЛЯ
}

Досліджено біоелектричні потенціали (БЕП) кореневої шийки дуба звичайного і липи дрібнолистої в 44-92-річних дубових деревостанах Західного Поділля. Лісостани ростуть в умовах свіжої грабової діброви та характеризуються різною часткою цих видів у складі деревостанів. Встановлено перевищення абсолютних середньоденних показників біопотенціалів дуба мішаних липово-дубових деревостанів над чистим дубовим деревостаном на 9,6-129,6 \%. Найбільші показники БЕП виявлено в лісостанах, де дуб перевищує липу за висотою і діаметром, а його частка у складі деревостанів становить 1-5 одиниць. Середньоденні біоелектричні потенціали липи дрібнолистої змінюються від $-58,6$ до -116,5 мВ. Встановлено, що в деревостанах, де частка липи у складі становить 5-6 одиниць, ії абсолютні середньоденні показники біопотенціалів перевищують показники чистого липового деревостану на 7,0-23,2 \%, а на ділянках з часткою липи 2-4 одиниці вони виявились істотно (на 14,4-38,1 \%) нижчими. Найкращі умови для функціонування дуба і липи склались в деревостанах, де частка дуба змінюється в межах 1-4 одиниць, а липи - від 4 до 6 одиниць. У денній динаміці впродовж першої половини дня знижуються абсолютні показники БЕП у дуба і липи та зростають у другій його половині. Кореляційні зв'язки між денною динамікою мікрокліматичних показників і динамікою БЕП у дуба і липи в різних деревостанах змінюються в дуже широкому діапазоні - від слабкої до дуже високої тісноти. Абсолютні показники БЕП характеризуються прямою залежністю 3 температурою повітря й інтенсивністю світла та зворотною - з вологістю повітря.

Ключові слова: біоелектричні потенціали; дуб звичайний; липа дрібнолиста; дубові деревостани.

Вступ. Ріст і формування деревостанів є інтегральним показником процесів життєдіяльності деревних видів. В умовах фітоценозів між видами і в межах виду виникають конкурентні взаємовідносини за світлове i грунтове живлення, що призводить до посилення диференціації дерев у деревостанах за біометричними і морфофізіологічними показниками. Інтенсивність життевих процесів у рослин інтегрально характеризують електрофізіологічні показники (Kolovskii, 1980; Krynytckyy, 1990; Krynytckyy \& Bondarenko, 1984). Teоретичні аспекти та природу виникнення біоелектричних потенціалів (БЕП) на різних рівнях організації рослинного організму висвітлено у низці робіт (Kolovskii, 1980; Opritov, 1964; Samuilov, 1968). У деяких роботах наведено результати вивчення зв'язку БЕП з фізіологічними процесами в деревних рослин (Kolovskii, 1973; Krynytckyy \& Bondarenko, 1984; Krynytskyi \& Zaika, 2004; Opritov, 1968; Samuilov, 1968). Так, Р. А. Коловський (Kolovskii, 1973) встановив тісний кореляційний зв'язок біопотенціалів 3 інтенсивністю транспірації, В. А. Опрітов (Opritov, 1968) - $з$ пересуванням речовин у ситовидних трубках, а Ф. Д. Самуілов (Samuilov, 1968) - $з$ поглинанням води рослинами. У сосни звичайної в умовах впливу хронічного іонізуючого опромінення встановлено значний i високий кореляційний зв'язок між інтенсивністю фотосинтезу і показниками біопотенціалів (Krynytskyi \& Zaika, 2004). Біопотенціали також тісно корелюють 3 інтенсивністю росту дерев за висотою і діаметром (Krynytckyy \& Zaika, 1991). Водночас Г. Т. Криницький i $\quad$ В. Д. Бондеренко (Krynytckyy \& Bondarenko, 1984) у підросту деревних видів не виявили тісних кореляційних зв'язків основних фізіологічних процесів з біоелектричними потенціалами. Вони показали, що величина БЕП визначається не окремим фізіологічним процесом, а сукупністю метаболічних перетворень, які відбуваються в кожній точці рослинного організму. Окрім цього, біоелектричні потенціали характеризуються чітко вираженою денною динамікою, яка корелює 3 динамікою мікрокліматичних чинників та відображає динаміку фізіолого-біохімічних процесів (Zaika, 1995; Kolovskii, 1973; Krynytskyi, 1993; Krynytskyi \& Zaika, 1995; Rutkovskii, 1973; Salna, 1964).

Треба зазначити, що останнім часом біоелектричні потенціали в лісівничих дослідженнях майже не використовуються. На нашу думку, біопотенціали $є$ достатньо об'єктивними показниками життєдіяльності рослин, які доцільно використовувати для дослідження взаємовідносин деревних видів під час формування деревостанів.

Об'єктом дослідження слугували процеси життєді-

Інформація про авторів:

Каленюк Юрій Степанович, викладач. Email: kaleniukyurii@gmail.com

Заїка Володимир Костянтинович, д-р біол. наук, професор, кафедра лісівництва. Email: vkzaika@ukr.net

Цитування за ДСтУ: Каленюк Ю. С., Заїка В. К. Біоелектричні потенціали дуба і липи в деревостанах свіжої грабової діброви Західного Поділля. Науковий вісник НЛтУ України. 2019, т. 29, № 1. С. 49-53.

Citation APA: Kalenyuk, Yu. S., \& Zaika, V. K. (2019). Bioelectric Potentials of Oak and Lime in the Stands of Fresh Hornbeam-Oak Forest of West Podillya. Scientific Bulletin of UNFU, 29(1), 49-53. https://doi.org/10.15421/40290110 
яльності дуба і липи в деревостанах свіжої грабової діброви Західного Поділля з різною часткою у їх складі липи дрібнолистої.

Предмет дослідження - біоелектричні потенціали дерев дуба і липи в дубових деревостанах різного породного складу свіжої грабової діброви Західного Поділля.

Мета дослідження - встановити вплив липи дрібнолистої на життєдіяльність дуба звичайного в деревостанах та його фізіологічний стан.

Дослідження проводили в дубових деревостанах за участю липи дрібнолистої віком від 41 до 92 років, які ростуть в умовах свіжої грабової діброви Західного Поділля. Частка липи у їх складі становить від поодиноких дерев до 6-8 одиниць. Серед них переважають деревостани 3 часткою липи 2-4 одиниці. Вони ростуть за II-I класами бонітету (Zaika \& Kaleniuk, 2018). На частині пробних ділянок ми дослідили біоелектричні потенціали.

Біоелектричну активність дуба звичайного і липи дрібнолистої вивчали за методикою Г. Т. Криницького (Krynytckyy, 1990; Krynytskyi, 1992). Для вимірювання біоелектричних потенціалів використовували високоомний біопотенціалметр і неполяризаційні хлорсрібні електроди. Вимірювання БЕП у дерев проводили на рівні кореневої шийки відносно Землі. Для дослідження відбирали по 15-20 модельних дерев кожного виду різної інтенсивності росту.

Результати дослідження. Складні конкурентні взаємовідносини між деревними видами в лісових фітоценозах визначають їх продуктивність і біологічну стійкість. Під час формування деревостанів враховують біологічні особливості видів та можливість виникнення між ними антагоністичних чи синергетичних взаємодій. Більшість дослідників вказують на позитивну роль липи дрібнолистої для дубових деревостанів (Hordiienko, $1996,2005)$. Однак наші дослідження показали, що липа дрібнолиста, як і будь-який інший деревний вид, за певних умов може пригнічувати ріст дуба (Zaika \& Kaleni$\mathrm{uk}, 2018)$. Для встановлення інтенсивності функціонування дуба і липи в деревостанах різного віку та видового складу використали біоелектричні потенціали. Середньоденні показники біоелектричних потенціалів дуба і липи наведено в табл. 1.

Табл. 1. Середньоденні показники біоелектричних потенціалів дуба і липи

\begin{tabular}{|c|c|c|c|c|c|c|c|}
\hline \multirow{2}{*}{$\begin{array}{l}\text { № } \\
\text { пр. } \\
\text { пл. }\end{array}$} & \multirow{2}{*}{$\begin{array}{c}\text { Склад } \\
\text { деревостану }\end{array}$} & \multirow{2}{*}{$\begin{array}{l}\text { Вік, } \\
\text { років }\end{array}$} & \multirow{2}{*}{$\begin{array}{c}\text { Дерев- } \\
\text { ний вид }\end{array} \mid$} & \multicolumn{4}{|c|}{ Показники } \\
\hline & & & & $M \pm m$ & $\%$ & $t_{\phi}$ & $V$ \\
\hline 1 & 10Лпд+Бп & 45 & Лпд & $-94,6^{ \pm 3,1}$ & 100,0 & 0,00 & 6 \\
\hline 13 & 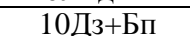 & & 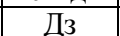 & -44 & 100,0 & 0,00 & \\
\hline \multirow[b]{2}{*}{3} & \multirow{2}{*}{$\begin{array}{c}6 \text { Ппд2Ясз1Дз } \\
1 \text { Бп+Гз, Взг, } \\
\text { Клг }\end{array}$} & \multirow[b]{2}{*}{45} & 3 & $-102,4^{ \pm 6,1}$ & 229,6 & 8,04 & 13 , \\
\hline & & & Лпд & $-101,2^{ \pm 3,0}$ & 107,0 & 1,53 & 14,8 \\
\hline \multirow{2}{*}{6} & \multirow{2}{*}{$\begin{array}{c}\text { 5Лпд3Дз2Гз+ } \\
\text { Кля }\end{array}$} & \multirow{2}{*}{56} & Д3 & $-82,6^{ \pm 4,2}$ & 185,2 & 6,71 & \\
\hline & & & Лпд & -110 & 123,2 & 3,38 & 16 \\
\hline \multirow{2}{*}{8} & \multirow{2}{*}{$\begin{array}{c}\text { 5Дз4Лпд1Гз+ } \\
\text { ЯсзКлгЧш }\end{array}$} & \multirow{2}{*}{55} & Д3 & $-77,8^{ \pm 4,6}$ & 174,4 & 5,56 & 25 \\
\hline & & & Лпд & $-107,6^{ \pm 3,6}$ & 113,7 & 2,74 & 13 \\
\hline \multirow{2}{*}{9} & \multirow{2}{*}{ 5Дз4Лпд1Гз } & \multirow{2}{*}{58} & Д3 & $-43,0^{ \pm 4,9}$ & 96,4 & 0,26 & 37, \\
\hline & & & Лпд & $-81,0^{ \pm 4,4}$ & 85,6 & 2,53 & 19 , \\
\hline \multirow{2}{*}{10} & \multirow{2}{*}{$\begin{array}{c}\text { 5Дз3Лпд1Кля } \\
1 Г з+Я с 3 \\
\end{array}$} & \multirow{2}{*}{41} & Д3 & $-57,3^{ \pm 3,8}$ & 128,5 & 2,36 & 29 , \\
\hline & & & Лпд & $-68,2^{ \pm 3,4}$ & 72,1 & 5,74 & 20 \\
\hline \multirow{2}{*}{20} & 2Дз5Гз2Лпд1 & \multirow{2}{*}{92} & Д3 & $-48,9^{ \pm 4,5}$ & 109,6 & 0,73 & 34 \\
\hline & Ясз+Клг, Взг & & Лпд & $-58,6^{ \pm 3,4}$ & 61,9 & 7,82 & 21 \\
\hline
\end{tabular}

Примітки: 1. Контролем для дуба був чистий дубовий деревостан (пр. пл. 13), а для липи - липовий деревостан (пр. пл. 1); 2. Табличне значення $t$-критерію Стьюдента становить 2,18 .
3 табл. 1 видно, що в дослідних деревостанів середньоденні показники біоелектричних потенціалів дуба змінюються в межах $-43,0--102,4$ мВ. Тільки на діл. 9 абсолютний показник БЕП кореневої шийки дуба виявився на 3,6 \% нижчим за контроль. На інших дослідних ділянках абсолютні значення біопотенціалів дуба перевищували контроль на 9,6-129,6\% $\left(t_{\phi}=0,73-8,04\right.$; $\left.t_{05}=2,18\right)$. Найбільшими вони $є$ в лісостанах на пр. пл. 3, 6 і 8. Дуб в цих деревостанах перевищує липу за висотою і діаметром, а його частка у їх складі становить 15 одиниць. У 92-річному деревостані (пр. пл. 20) висота дуба і липи виявились на одному рівні (Zaika \& Kaleniuk, 2018).

Середньоденні біоелектричні потенціали липи дрібнолистої змінюються від -58,6 до -116,5 мВ. Такі великі відмінності між деревостанами за показниками БЕП липи зумовлені умовами ії росту та впливом на неї інших деревних видів. Встановлено, що на діл. 3, 6 і 8 абсолютні середньоденні показники біопотенціалів липи перевищують контроль на 7,0-23,2\% $\quad\left(t_{\phi}=1,53-3,38\right.$; $\left.t_{05}=2,18\right)$, а на діл. 9, 10 і 20 вони виявились істотно на $14,4-38,1 \%\left(t_{\phi}=2,53-7,82\right)$ нижчими за нього. Найкращі умови для функціонування дуба і липи склались в деревостанах на пр. пл. 3, 6 і 8, де частка дуба змінюється в межах 1-4 одиниць, а липи - від 4 до 6 одиниць. У 55річному (пр. пл. 8) і 92-річному (пр. пл. 20) деревостанах спостерігаються найменш сприятливі фітоценотичні умови для життєдіяльності дуба і липи.

Варіювання дерев дуба в деревостанах за середньоденними показниками біопотенціалів виявилось переважно сильним, а липи - середнім. На нашу думку, визначальним фактором, який впливає на мінливість функціональних процесів у деревних видів у лісових фітоценозах $є$ їх відношення до світла. Дуб звичайний, як світлолюбний вид, $є$ більш чутливий до світлових умов, ніж липа дрібнолиста. Біологічні особливості деревних видів та їх реакція на денні зміни мікрокліматичних умов в деревостанах зумовлюють денні динаміки біопотенціалів (рисунок).

3 рисунка видно, що динаміка денних змін біоелектричних потенціалів кореневої шийки дуба і липи значною мірою визначається умовами, які склалися в деревостанах у процесі їх формування. Так, на діл. 1 у чистому 45-річному липовому деревостані БЕП кореневої шийки упродовж дня змінювались слабо в межах -90 - 100 мВ. Упродовж першої половини дня у липи на цій ділянці спостерігалося незначне зростання абсолютних показників БЕП і зниження у другій його половині. У дуба звичайного в чистому деревостані (пр. пл. 13) на денній біопотенціалограмі спостерігається два мінімуми. Перший виник о 13-й год після істотного зниження абсолютних показників БЕП у першій половині дня, а другий, більш глибокий, о 17-й год після незначного їх зростання до 15-ї години. Після досягнення мінімуму о 17-й годині абсолютні показники біопотенціалів до кінця дня характеризуються зростанням. В інших деревостанах найбільшу подібність денних змін біопотенціалів у дуба виявлено на діл. 6, 8, 9 і 20. На них абсолютні показники біопотенціалів у дуба інтенсивно знижуються до 13-17-ї год, а потім зростають до кінці дня. На діл. 3 встановлено різке зменшення абсолютних значень БЕП до 13-ї години й інтенсивне збільшення упродовж другої його половини. У липи дрібнолистої характер денних біопотенціалограм на дослідних ділянках 
переважно є подібним до дуба звичайного. Однак липа за абсолютними показниками БЕП упродовж дня характеризується вищими значеннями від дуба. Необхідно
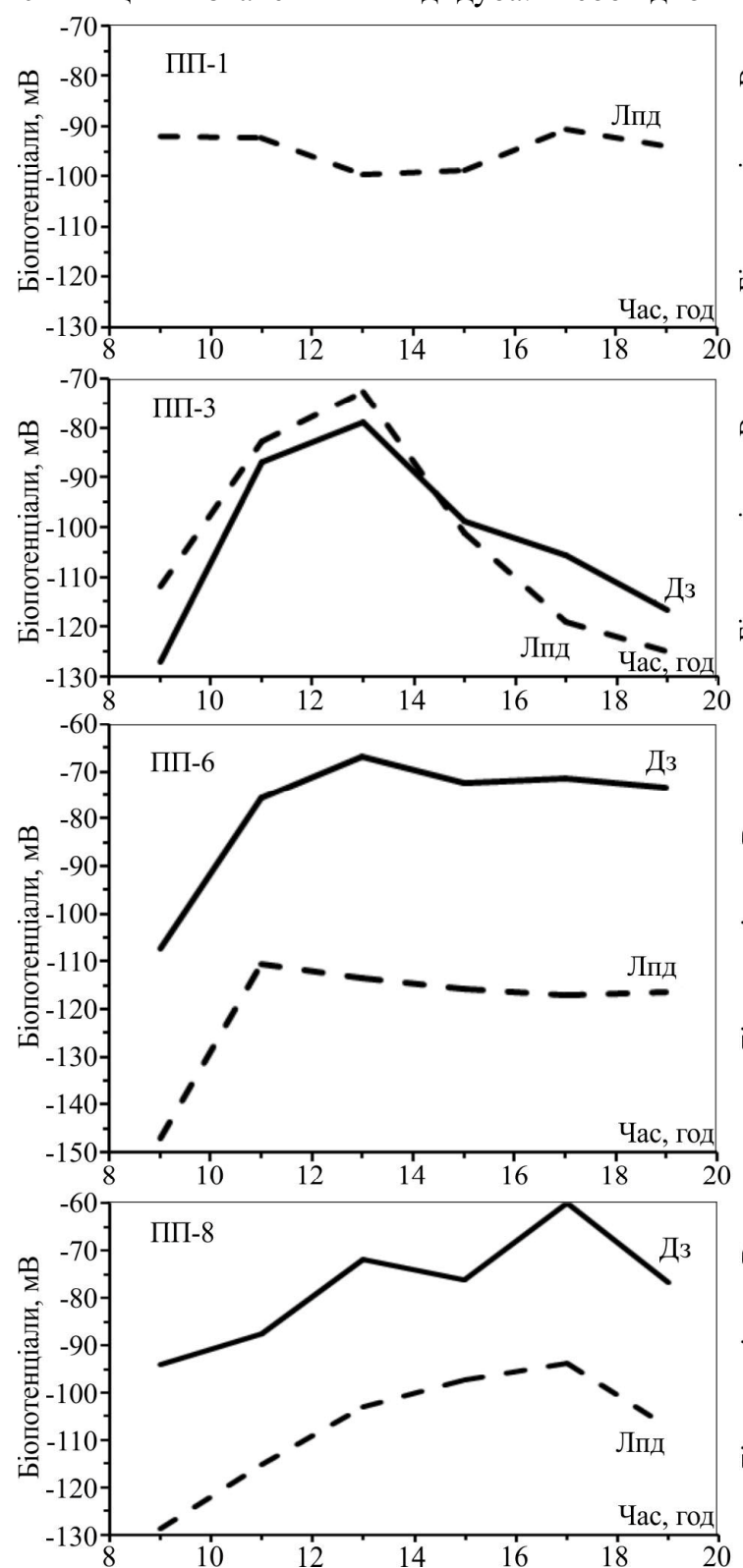

Рисунок. Денна динаміка біопотенціалів дуба і липи в деревостанах Західного Поділля
Табл. 2. Коефіцієнти кореляції між біометричними показниками дерев і мікрокліматичними показниками та біопотенціалами

\begin{tabular}{|c|c|c|c|c|c|c|}
\hline \multirow{2}{*}{$\begin{array}{c}\text { № } \\
\text { п/п }\end{array}$} & \multirow{2}{\text{Дерев-}}{\begin{tabular}{c} 
ний вид \\
\cline { 3 - 7 }
\end{tabular}} & $\begin{array}{c}\text { висо- } \\
\text { та }\end{array}$ & $\begin{array}{c}\text { ді- } \\
\text { аметр }\end{array}$ & $\begin{array}{c}\text { температу- } \\
\text { ра повітря }\end{array}$ & $\begin{array}{c}\text { вологість } \\
\text { повітря }\end{array}$ & $\begin{array}{c}\text { інтенсив- } \\
\text { ність світла }\end{array}$ \\
\hline 1 & Лпд & 0,130 & 0,324 & 0,523 & $-0,645$ & 0,824 \\
\hline 13 & Дз & 0,336 & 0,333 & 0,081 & $-0,330$ & 0,435 \\
\hline \multirow{2}{*}{3} & Дз & 0,393 & 0,559 & 0,640 & $-0,499$ & 0,468 \\
\cline { 2 - 7 } & Лпд & 0,598 & 0,435 & 0,217 & $-0,011$ & 0,317 \\
\hline \multirow{2}{*}{6} & Дз & 0,376 & 0,119 & 0,613 & $-0,589$ & 0,131 \\
\cline { 2 - 7 } & Лпд & 0,258 & 0,337 & 0,542 & $-0,620$ & 0,243 \\
\hline \multirow{2}{*}{8} & Дз & 0,037 & 0,290 & 0,218 & $-0,498$ & 0,641 \\
\cline { 2 - 7 } & Лпд & 0,527 & 0,534 & 0,041 & $-0,350$ & 0,615 \\
\hline \multirow{2}{*}{9} & Дз & 0,083 & 0,549 & 0,065 & $-0,502$ & 0,487 \\
\cline { 2 - 7 } & Лпд & 0,525 & 0,572 & 0,270 & $-0,338$ & 0,173 \\
\hline \multirow{2}{*}{10} & Дз & 0,081 & 0,258 & 0,543 & $-0,615$ & 0,151 \\
\cline { 2 - 7 } & Лпд & 0,699 & 0,710 & 0,425 & $-0,501$ & 0,009 \\
\hline \multirow{2}{*}{20} & Дз & 0,109 & 0,155 & 0,980 & $-0,973$ & 0,177 \\
\cline { 2 - 7 } & Лпд & 0,336 & 0,498 & 0,983 & $-0,966$ & 0,019 \\
\hline
\end{tabular}

відзначити діл. 6, 8 і 9, де ці відмінності між дубом і липою є найбільшими.
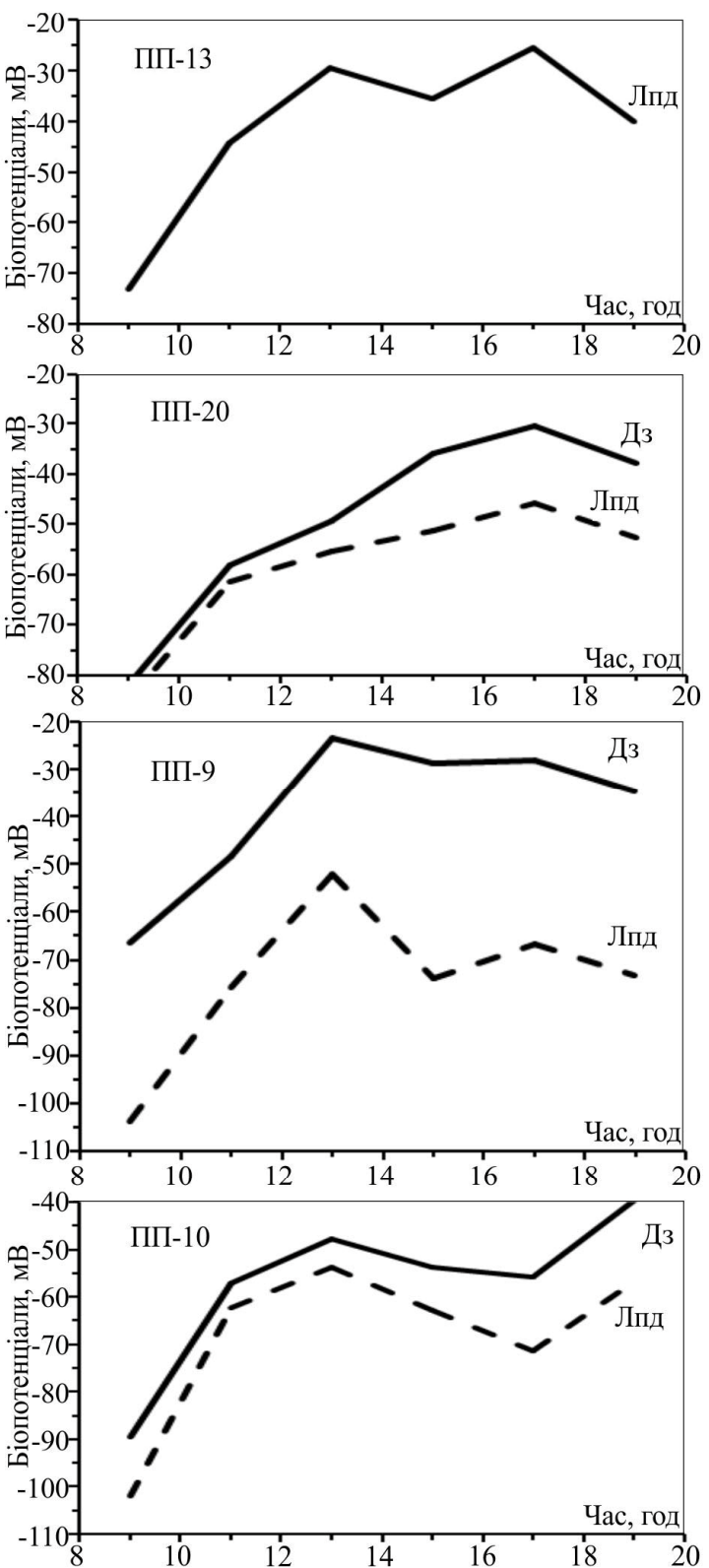

На показники біоелектричної активності значною мірою впливають зовнішні мікрокліматичні чинники та біометричні показники дерев. Ми досліджували кореляційні зв'язки між біометричними показниками дерев i середньоденними показниками біопотенціалів, а також між денними змінами мікрокліматичних показників i денною динамікою біопотенціалів (табл. 2).

3 табл. 2 видно, що коефіцієнти кореляції між висотою і діаметром модельних дерев дуба і липи та середньоденними показниками БЕП переважно коливаються від слабкої до значної тісноти. На його величину істотно впливають фітоценотичні умови, а саме взаємовідносини між деревними видами у конкуренції за світлове грунтове живлення. Умови перебування дерев у фітоценозі визначають їх реакцію також на мікрокліматичні чинники. Кореляційний зв'язок між їх денною динамікою і динамікою БЕП у дуба і липи коливаються в дуже широкому діапазоні - від слабкої до дуже високої тісноти. Абсолютні показники БЕП ха- 
рактеризуються прямою залежністю 3 температурою повітря й інтенсивністю світла та зворотною - 3 вологістю повітря. Дуже високий кореляційний зв'язок біопотенціалів 3 температурою і вологістю повітря виявлено у дуба і липи в 92-річному деревостані на діл. 20 і слабкий з освітленістю. Дуб і липа в цьому деревостані за висотою ростуть на одному рівні, а за діаметром липа істотно перевищує дуба (Zaika \& Kaleniuk, 2018). У деревостанах на діл. 3, 6, 10 і 20 в дуба встановлено тісніший зв'язок біопотенціалів з температурою повітря, ніж з освітленістю. На інших ділянках на величину БЕП більшою мірою впливає інтенсивність світла, аніж температура. Біопотенціали липи більшою мірою залежать від температури, ніж від інтенсивності світла на діл. 6, 10 і 20. Високу кореляційну залежність БЕП липи від освітленості встановлена в 45-річному чистому липовому деревостані (пр. пл. 1).

Висновки. Встановлено перевищення абсолютних показників біопотенціалів дуба мішаних липово-дубових деревостанів над чистим дубовим деревостаном на 9,6-129,6\%. Найбільшими вони виявились в лісостанах, де дуб перевищує липу за висотою і діаметром, а його частка у їх складі становить 1-5 одиниць. У липи, де іï частка у складі деревостанів становить 5-6 одиниць, їі абсолютні середньоденні показники біопотенціалів перевищують показники чистого липового деревостані на 7,0-23,2 \%, а на ділянках з часткою липи 24 одиниці вони виявились істотно (на 14,4-38,1\%) нижчими. Найкращі умови для функціонування дуба і липи склались в деревостанах, де частка дуба змінюється в межах 1-4 одиниць, а липи - від 4 до 6 одиниць. У денній динаміці впродовж першої половини дня спостерігається зниження абсолютних показників БЕП у дуба i липи та зростання у другій його половині. Кореляційні зв'язки між денною динамікою мікрокліматичних показників і динамікою БЕП у дуба і липи в різних деревостанах коливаються в дуже широкому діапазоні - від слабкої до дуже високої тісноти. Абсолютні показники БЕП характеризуються прямою залежністю 3 температурою повітря й інтенсивністю світла та зворотною - 3 вологістю повітря.

\section{Перелік використаних джерел}

Hordiienko, M. I. (1996). Lypa dribnolysta i kultury z yii uchastiu. Kyiv: Silhosposvita, 224 p. [In Ukrainian].

Hordiienko, M. I. (2005). Lisivnychi vlastyvosti derevnykh roslyn. Kyiv: Vistka, 816 p. [In Ukrainian].

Kolovskii, R. A. (1973). Vliianie otnositelnoi vlazhnosti vozdukha na velichinu bioelektricheskogo potentciala drevesnykh rastenii. Forest Studies, 6, 53-59. [In Russian].
Kolovskii, R. A. (1980). Bioelektricheskie potentcialy drevesnykh rastenii. Novosibirsk: Nauka, 176 p. [In Russian].

Krynytckyy, G. T. (1990). Bioelektricheskii metod opredeleniia zhiznesposobnosti drevesnykh rastenii na nachalnykh etapakh ontogeneza. Scientific and Production Association of Space Research, 85, 61. [In Russian].

Krynytckyy, G. T., \& Bondarenko, V. D. (1984). Issledovanie sviazi bioelektricheskikh potentcialov s osnovnymi fiziologicheskimi protcessami podrosta drevesnykh rastenii. Forestry, forestry, paper and woodworking industry, 15, 15-18. [In Russian].

Krynytckyy, G. T., \& Zaika, V. K. (1991). Bioelektricheskaia aktivnost polusibsovykh potomstv sosny obyknovennoi v sviazi s intensivnostiu rosta. Materials of the 40th Scientific and Technical Conference of the Lviv Forestry Institute, Lviv, February, 1988. (pp. 83-85). [In Russian].

Krynytskyi, H. T. (1992). Pro metodyku vykorystannia elektrofiziolohichnykh pokaznykiv dlia vyznachennia zhyttiezdatnosti derevnykh roslyn. Forestry, Forest, Paper and Woodworking Industry, 23, 310. [In Ukrainian].

Krynytskyi, H. T. (1993). Morfofiziolohichni osnovy selektsii derevnykh roslyn. Abstract Of Doctoral Dissertation For Biology Scientific (06.03.01 - Forest crops and Phytomelioration) (03.00.12 Plant Physiology). Kyiv, 46 p. [In Ukrainian].

Krynytskyi, H. T., \& Zaika, V. K. (1995). Vplyv osoblyvostei formuvannia molodykh pivsibsovykh nasadzhen sosny zvychainoi na bioelektrychnu aktyvnist derev. Scientific Bulletin of UNFU, 4, 153-160. [In Ukrainian].

Krynytskyi, H. T., \& Zaika, V. K. (2004). Elektrofiziolohichna reaktsiia kultur sosny zvychainoi na vysoki rivni khronichnoho radiatsiinoho oprominennia. Status and trends of development of forestry education, science and forestry in Ukraine, 14(5), 8-14. [In Ukrainian].

Opritov, V. A. (1964). Bioelektricheskie potentcialy i peredvizhenie veshhestv u rastenii. Physico-chemical basis of the origin of Biopotentials, 12, 169-174. [In Russian].

Opritov, V. A. (1968). O roli bioelektricheskikh potentcialov v postuplenii i peredvizhenii veshhestv u rastenii. Biophysics, 3(1), 3844. [In Russian].

Rutkovskii, I. V. (1973). Bioelektricheskaia aktivnost topolei raznogo fiziologicheskogo sostoianiia v sutochnom i sezonnom ritmakh. Forest Studies, 1, 51-57. [In Russian].

Salna, L. A. (1964). Izmenenie bioelektricheskikh potentcialov rastenii pod vliianiem vneshnikh uslovii. Physico-chemical basis of the origin of Biopotentials, 12, 165-168. [In Russian].

Samuilov, F. D. (1968). O vozmozhnosti uchastiia bioelektricheskikh potentcialov v pogloshhenii vody rasteniiami. Plant physiology, 15(4), 709-712. [In Russian].

Zaika, V. K. (1995). Selektsiino-ekolohichni osoblyvosti formuvannia pivsibsovykh potomstv sosny zvychainoi $\mathrm{v}$ umovakh Lvivskoho Roztochchia. Abstract of Candidate Dissertation for Agricultural Sciences (06.00.18 - Forestry, Breeding, Seeding and Planting of Greenery in Cities). Lviv: UkrDLTU, 23 p. [In Ukrainian].

Zaika, V. K., \& Kaleniuk, Yu. S. (2018). Rist i formuvannia dubovykh derevostaniv za uchastiu lypy dribnolystoi v umovakh svizhoi hrabovoi dibrovy Zakhidnoho Podillia. Proceedings of the Forestry Academy of Sciences of Ukraine, 17, 37-45. [In Ukrainian].

Yu. S. Kalenyuk ${ }^{1}$, V. K. Zaika

${ }^{1}$ Kremenetskiy Forestry College, Bilokrynytsya, Ukraine

${ }^{2}$ Ukrainian National Forestry University, Lviv, Ukraine

\section{BIOELECTRIC POTENTIALS OF OAK AND LIME IN THE STANDS OF FRESH HORNBEAM-OAK FOREST OF WEST PODILLYA}

The bioelectric potentials (BEP) of the root collars of European oak and small-leaved lime have been studied in the 44-92-yearold oak forests of West Podillya. To measure the bioelectric potentials, a high-ohmic biopotentialimeter and non-polarizing silverchloride electrodes were used. The measurement of daytime dynamics of BEP in the trees was carried out at the level of the root collar with respect to ground. For the study, 15-20 model trees of each species of different rates of growth were selected. The stands grow in conditions of fresh hornbeam-oak forest and are characterized by varying proportions of these species in the composition of the stands. It is found that the absolute average daily values for biopotentials of oak in mixed lime-oak stands exceed the oak biopotential values in pure oak stands by 9.6-129.6. The highest values of BEP were found in the forest stands, where the oak exceeds the lime in height and diameter, and its share in the forest stands is $1-5$ units. The average daily bioelectric potentials of small-leaved li- 
me range from -58.6 to $-116.5 \mathrm{mV}$. We have found that in the forest stands, where the share of lime in the forest stand composition is 5-6 units, its absolute average daily values of biopotentials exceed the indexes of pure lime stands by 7.0-23.2\%, while in the areas with a share of lime of 2-4 units, these values were found to be significantly lower by14.4-38.1\%. In the daytime dynamics during the first half of the day, there is a decrease in absolute values of BEP in oak and lime. In the second half of the day, in some stands, the biopotentials in oak and lime increased by the end of the day, while in other stands, after a slight increase, they again decreased. In general, the absolute biopotential indexes of lime are higher than those in oak. The correlation between the daytime dynamics of microclimatic parameters and the dynamics of BEP in oak and lime in different stands varies in a very wide range - from weak to a very high level of relationship. The strength of correlation relationship depends on the silvicultural parameters of forest stands and the interaction of woody species in the forest stands. The absolute indexes of BEP are characterized by direct dependence on the air temperature, intensity of light, and the reverse humidity of the air. The best conditions for the functioning of oak and lime were in the stands, where the proportion of oak varies within 1-4 units, and lime - from 4 to 6 units.

Keywords: bioelectric potentials; European oak; small-leaved lime; oak stands; forest-stand composition. 